\title{
Relationship between Entrepreneurial Personality, Performance, Job Satisfaction and Operations Strategy: An Empirical Examination
}

\author{
Atul Gupta ${ }^{1} \&$ Sharon R. Muita ${ }^{2}$ \\ ${ }^{1}$ School of Business \& Economics, Lynchburg College, Lynchburg, VA, United States \\ Correspondence: Atul Gupta, School of Business \& Economics, Lynchburg College, Lynchburg, VA, United \\ States. Tel: 1-434-544-8651. E-mail: Gupta@Lynchburg.Edu
}

Received: October 24, 2012 Accepted: November 6, 2012 Online Published: December 22, 2012

doi:10.5539/ijbm.v8n2p86

URL: http://dx.doi.org/10.5539/ijbm.v8n2p86

\begin{abstract}
The goal of this research paper is to study the possible interactions between operations strategy and entrepreneurial traits, performance and job satisfaction. This empirical paper used a non-experimental design to test a proposed model based on a review of relevant literature. The study was conducted with 1200 SMEs in the Lynchburg City region using an administered survey instrument. The results of this study indicate that entrepreneurial personality has statistically significant relationship with Performance and Operations Strategy. The relationship between entrepreneurial personality and Job Satisfaction was not statistically significant. Operations strategy has statistically significant moderating role in the relationship between entrepreneurial personality and performance. The research framework offers a different way forward for both practitioners and academicians in thinking about the factors which may be critical for the success of SMEs.
\end{abstract}

Keywords: entrepreneurial personality, performance, operations strategy, job satisfaction

\section{Introduction}

Although much attention has been paid to the study of Small and Medium Sized Enterprises (SMEs), there has been surprisingly little research on the possible interactions among operations strategy, entrepreneurial personality traits, performance and job satisfaction. Much of the existing literature on SMEs focuses on the business owners' personality factors and performance or performance and job satisfaction. Fewer research studies have investigated how personality relates to entrepreneurs' choice of operations strategies (OS) or how having an operations strategy (OS) relates to entrepreneurial performance and job satisfaction. In this study, an attempt is made to understand the linkages among entrepreneurial traits, operations strategy, performance, and job satisfaction. The information reported in this paper is intended to establish a stronger foundation for understanding the link among operations strategy, personality, performance and job satisfaction for those who intend to become entrepreneurs. This paper is organized as follows. In the following section we begin with a research questions and review of the existing literature, followed by the empirical examination of research questions.

\section{Research Questions}

Pursuing this endeavor, the overall objective of this research was refined by asking the following questions:

Research Question 1: What is the extent to which the relationship between operations strategy, entrepreneurial performance and job satisfaction in case of SMEs is explained by entrepreneurial personality traits?

Research Question 2: What is the extent to which the performance is explained by operations strategy? Is it worth having an operations strategy in place for a successful organization?

Research Question 3: What is the extent to which the relationship between entrepreneurial personality traits and entrepreneurial performance is affected by operations strategy and job satisfaction?

With these questions in mind, this research attempts to measure the impact of various factors on the entrepreneurial performance. 


\section{Literature Review}

\subsection{Entrepreneurship Research}

Small businesses play an important and vital role in the free-enterprise economic system throughout the world and they have long been recognized and acknowledged for their important contribution to economic growth and prosperity both nationally and internationally. The small business sector represents a statistically significant proportion of the world economy (Morrison et al, 2003) and United States is one of the strongest entrepreneurial countries in the world (Zacharakis et al, 2003). For example, small businesses represent 99.7 percent of all employers in the United States (Small Business Administration 2000). According to the latest Internal Revenue Service information, there are 18.6 million small businesses in the United States. Likewise, the U.S. Small Business Administration reports that small businesses account for $58 \%$ of the U.S. employment and $40 \%$ of the gross national product. Above all, a National Science Foundation analysis reveals that small businesses have been a more productive source of innovation per research and development dollar than large businesses. Researchers have observed that a great deal of the forward motion for change, innovation, job creation and progress in the U.S. economy comes from entrepreneurs (Morrison et al, 2003, Cromie, 2000; Reynolds et al, 2002; Acs, 1999; Reynolds 1997; Light and Rosenstein 1995; Drucker 1985; Schumpeter 1934).

\subsection{Entrepreneurial Personality}

Even though the history of psychological assessment in the US dates back to the period of World War I, the utilization of personality characteristics as it pertains to entrepreneurship first occurred about four decades ago (Davis, 2001). The psychological approach to the study of entrepreneurship emerged in the 1960s, particularly with the work of McClelland at Harvard University (McClelland, 1961; 1965). McClelland's research linked the need for achievement and entrepreneurial tendencies. Several other influential research studies were also conducted in the same period of time to study the link between personality and entrepreneurship (Collins and Moore, 1964; Smith, 1967). Over the last four decades, a large array of psychological characteristics has been examined as possible causes of entrepreneurial performance (Welsh et al, 1978; Welsch \& Young, 1982, Sexton \& Bowman, 1986; Churchill and Lewis, 1986; Sandberg, 1986 Goldberg, 1990; Herron and Robinson, 1993; Miner, 1996, Stewart et al, 1999; Rauch and Frese, 2000; Zacharakis et al, 2003; Breen, 2004; Ciavarella et al, 2004; Thurik and Wennekers, 2004).

Much of the personality related entrepreneurial research was observed for traits that determine who is more likely to start a business. McClelland (1961) observed that entrepreneurs had a higher need for achievement than non-entrepreneurs. He also found that entrepreneurs were moderate risk takers.

\subsection{Operations Strategy}

Strategies are actions that provide the guidance for the achievement of organizational goals. The term "strategy" generally means the direction and scope of a firm over the long term, and strategic decisions are generally broad, encompassing details about product range, market scope, competitive approach and research initiatives (McCarthy, 2003; Wickham, 1998). Very often strategy is defined as a formal plan. It is accepted that an optimal strategic plan can be developed if top management performs a detailed analysis of the firm, its product-market and environment (Lambin, 1997). Porter (1996) argued the essence of strategy is choosing to perform activities differently from rivals, which requires creativity and insight. Strategy is used mainly at three levels: Corporate strategy, Business strategy and Functional strategy

Operations strategy can occur in two places within this hierarchy, first at the corporate level, taking a broad perspective over a set of related or separate businesses and second, it can occur as one of the functional strategies at the business level. Operations strategy is viewed as the effective use of manufacturing strength as a competitive weapon for the achievement of business and corporate goals (Swamidass and Newell, 1987). Swamidass and Newell (1987) in an empirical study of 35 firms found a positive relationship between the performance of the firm (growth) and the higher the role of operations managers in the firm's strategic decision-making process. Clearly operations strategies are priorities and patterns of decisions of the manufacturing function in the pursuit of competitive advantage (Swamidass, Baines and Darlow, 2001). Skinner $(1969 ; 1974)$ for the first time observed that a company's operations function could do more than simply produce and deliver the products and services.

The contributions of operations are realized through the deployment of strategic decisions in various operational areas and aligning the firm's skills and resources with its competitive strategy and enhancing its ability to compete on these strategic dimensions (Pun et al, 2004). Kerr and Greenhalgh (1991) also suggest that manufacturing capabilities can be achieved through aligning these competitive priorities with the requirements of 
the competitive marketplace. Hayes and Wheelwright (1985), however, argue that firms should go beyond aligning these capabilities with the market. They suggest that deploying policies throughout the firm and developing a mission can help in achieving strategic goals. Operations strategy reflects organizational strategies and enables the operations function to contribute to the long-term competitive advantage and performance of the business (Skinner, 1974, Wheelwright $\&$ and Heyes, 1986).

\subsection{Entrepreneurial Performance}

Research shows both financial and non-financial performance measures are used for assessing entrepreneurial success. Some entrepreneurial researchers have attempted to define success in terms of growth (Perren, 2000), sustainability and turnover, while others have examined entrepreneurial characteristics and traits contributing to success and the organizational characteristics as indicators of success (Simpson et al, 2004).

Traditionally, performance measurement has been viewed as an important requirement of a cybernetic model of control that also includes stated objectives or goals, a predictive model and a tool to facilitate the choice of alternative actions (Henri, 2004, p.103). Gradually, financial measures became the yardstick for assessing performance of for-profit organizations. Since the early 1980s, however, there has been a growing understanding that, given the increased complexity of organizations and the markets in which they compete, it is no longer appropriate to use financial measures as the sole criteria for assessing success (Kennerley and Neely, 2002).

\subsection{Entrepreneurial Job Satisfaction}

Entrepreneurial job satisfaction has been widely researched over the last few decades (Currivan, 1999, Scarpello and Campbell, 1983, Locke, 1969). In recent research there appears to be agreement that job satisfaction is defined and measured both as a global construct and as a concept with multiple dimensions or facets (Mehta and Cooper, 2000; Frese et al, 2000; Locke, 1970).

\subsection{Linking Personality and Performance}

Baum and Locke (2004) examine the relationship between entrepreneurial traits and the impact that it has upon the growth of a venture. Examining a sample of 229 entrepreneur-CEOs and 106 associates in a 6-year longitudinal study, researchers found that entrepreneurial personality and traits have a direct effect on venture growth.

Wijewardena, Nanayakkara and De Zoysa (2008) found that there is a significantly strong relationship between owner/managers' perfsonality and the financial performance of companies.

De Zoysa and Herath (2007) determined that the stronger the entrepreneurial personality of the manager, the greater the performance of the firm is. Dickers, Jansen, de Lange, Vinkenburg and Kooij (2010) found that an entrepreneurial personality is associated with increased engagement and thereby better performance. McKenna (1996) concluded that entrepreneurs can sometimes negatively affect performance of a firm through the "dark side" of their personality. Julian \& Ahmed (2012) pointed out that one way for entrepreneurs to enhance their performance is to expand their business towards export markets.

\subsection{Entrepreneurial Personality and Job Satisfaction}

Using a sample of 202 fulltime workers, Furnham, Eracleous, and Chamorro-Premuzic (2009) found that $11-15 \%$ of the variance in job satisfaction stems from personality and other demographic variables. Thomas, Buboltz and Winkelspechy (2004) examined the relationship between personality and job satisfaction and found that personality did not have a direct effect on job satisfaction.

\subsection{Personality and Strategy}

The business activity of a new firm is often developed as a part of the entrepreneur's personal life strategy, as a means of earning a living, and is to a large extent characterized by the entrepreneur's personality characteristics (Littunen, 2000). Qureshi, Hayat, Mehwish and Sarway (2011) examine the implications of job satisfaction and organizational commitment on employee performance. Results collected from an analysis of a questionnaire from different organizations in Rawalpindi shows a positive relationship between job satisfaction and organizational commitment with overall employee performance. Crow and Hartman (1995) suggest that job satisfaction and performance are related, in that as satisfaction increases, performance will improve. They encourage managers to improve job satisfaction as a means of increasing performance. Gu and Siu (2009) determined that job satisfaction was significantly correlated with job performance in the labor force. They claim that increased support and benefits improve satisfaction and thereby further performance. In a sample of 202 employees, Crossman and Abou-Zaki(2003) found that job satisfaction does not independently relate to all job facets and that increased satisfaction in one area may lead to furthered satisfaction in another. They also 
determined that job performance was found to increase with more satisfaction and additionally tenured positions. Rodriquez-Escudery, Carbonell and Munuera-Aleman (2010) discovered that there was not an association between the pressure on an individual for performance and his or her satisfaction with the job and that different stressors lead to different reactions in regards to performance. The researchers found that all three stressors tested have an indirect "effect on market success via job satisfaction, adherence to budget and schedule, or product quality."

\subsection{Performance and Operations Strategy}

Schniederjans and Cao (2009) attempt to determine the relationship between operations strategy and business performance. From a sample of 176 organizations, they found that there is not a direct relationship between operations strategy and business performance; however, the perception that Operations Managers and General Managers have of operations strategy does have an impact upon business performance.

Brown, Squire and Lewis (2010) looked into links between types of strategic formulation and operations performance in a range of key parameters using a sample of the personal computer industry. They found that the capabilities of the operations performance were developed by specific strategic operational strategies. Ahmed, Montagno and Firenze (1996) found that companies using a variety of operational strategies experienced an increased level of performance. However, after several successive operational strategy implementations, the benefits became marginal.

\section{Sample and Methodology}

One of the problems with a study of small businesses is the lack of a commonly accepted method to distinguish between small, medium, and large firms. One of the common criteria is number of employees (Behesti, 2004). We classified any organization having between 10 and 499 employees as an SME (Behesti, 2004). The initial sample of 1200 businesses was drawn from the members of a Chamber of Commerce in the South Eastern United States using systematic sampling. The questionnaire used in this study has already been tested. The first mailing was sent out through e-mail followed by a reminder e-mail after three months. The questionnaire was also tested for reliability. The Cronbach alpha values range from 0.66 to 0.815 . Accordingly, the measures developed in this study were judged reliable. Once the reliability of the measures had been established, construct and criterion related validity of the questionnaire was also established. A total of 142 usable questionnaires were returned, providing a response rate of 11.83 percent. An "extrapolation procedure" was used to assess non-response bias. This assumes that "late" respondents are similar to the "theoretical" non-respondents (Armstrong and Overton, 1977). Independent t-tests were used to determine whether significant differences exist between the entrepreneurial personality and performance between the two sub-samples consisting of the respondents in the first and last quartile. No significant differences were found between the two sub-samples for any of the variables. The results suggest that there appears to be no significant differences between respondents and non-respondents for the variables under study and sample can be considered sufficient to draw conclusions about small businesses for the issues under study.

A series of regressions were run using entrepreneurial personality as the dependent variable and Job Satisfaction, Performance, and Operations Strategy as independent variables (Figure 1). Regression was also run using Performance as dependent variable and Operations strategy as the independent variable (Figure 2). We also examined the moderating influence of job satisfaction in relationship between entrepreneurial personality and performance as well as the moderating influence of operations strategy in relationship between entrepreneurial personality and performance (Figure 3). In order to investigate the moderating hypotheses, we performed hierarchical regression analysis. We used moderated regression analysis and used Performance as the dependent variable (Cohen \& Cohen, 1983). In step 1 the independent variable was introduced followed by moderating variables, operations strategy and job satisfaction, in the step 2 was introduced in the regression analysis. Next two-way interactions (entrepreneurial personality $\mathrm{x}$ job satisfaction, entrepreneurial personality $\mathrm{x}$ operations strategy) with job satisfaction and operations strategy were entered into the equation one at a time in the step 3. 


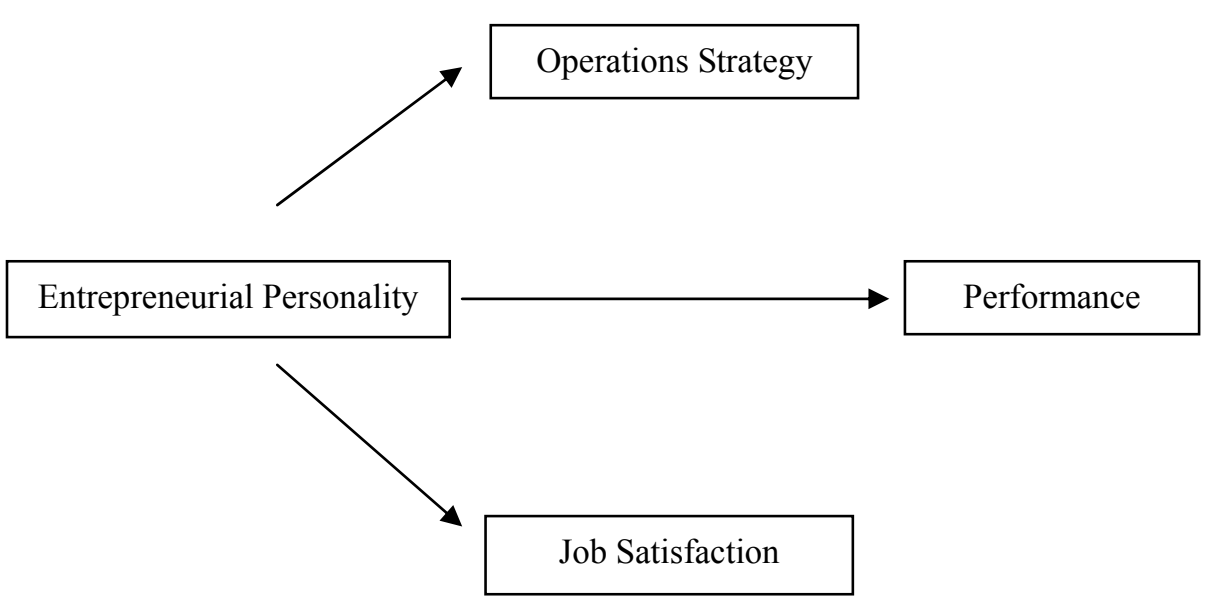

Figure 1. Relationship between entrepreneurial personality, operations strategy, job satisfaction and performance

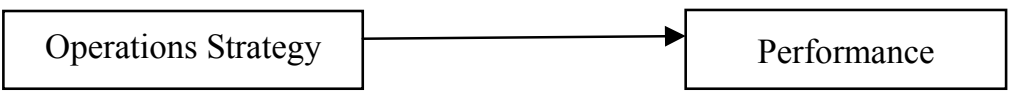

Figure 2. Relationship between operations strategy and performance

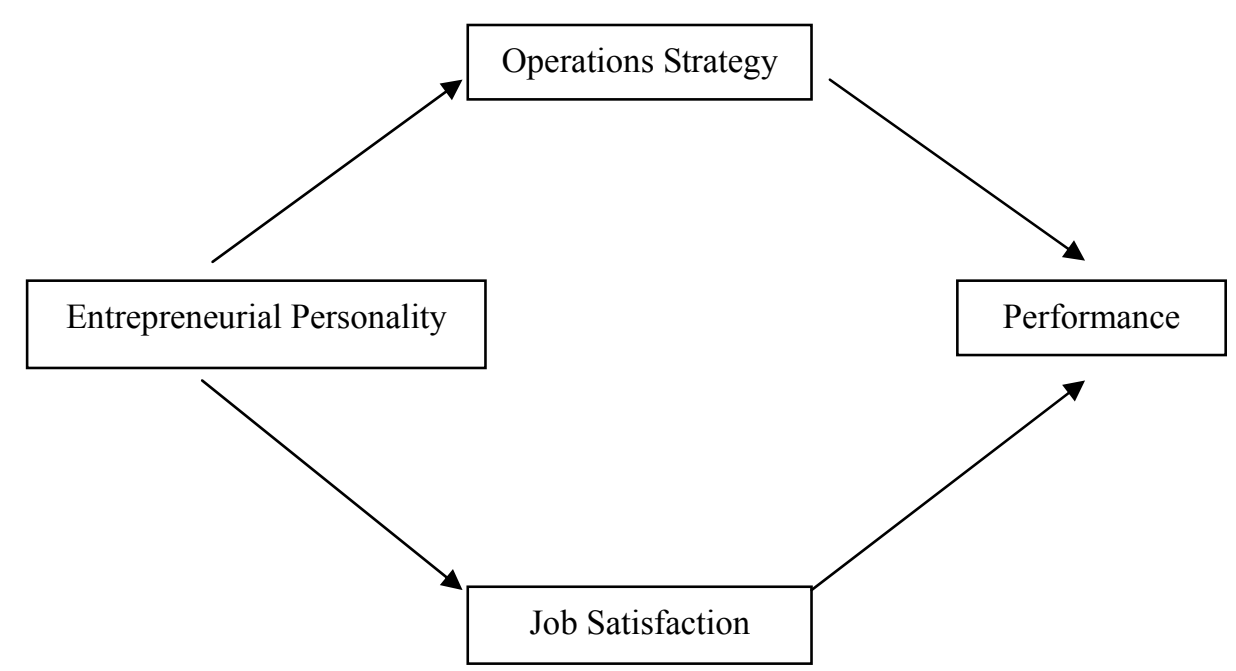

Figure 3. Moderating role of operations strategy and job satisfaction in the relationship between entrepreneurial personality and performance

\section{Results}

The results of this study indicate that entrepreneurial personality has statistically significant relationship with Performance and Operations Strategy (Table 1). The relationship between entrepreneurial personality and Job Satisfaction was not statistically significant (Table 2). The variables performance and operations strategy also has statistically significant relationship. With moderating analysis, both interaction terms were different from zero and statistically significant only for operations strategy. Findings of moderation analysis have shown that entrepreneurial personality affect performance more strongly and positively among those having an operations strategy in place (Table 3). 
Table 1. Entrepreneurial personality, performance, job satisfaction and operations strategy

\begin{tabular}{lc}
\hline & Standardized Coefficients \\
\cline { 2 - 2 } & Entrepreneurial Personality \\
\hline Performance & $0.186^{* *}$ \\
Job Satisfaction & 0.014 \\
Operations Strategy & $0.122^{*}$ \\
\hline$* \mathrm{p}<0.00, * * \mathrm{p}<0.05$ &
\end{tabular}

Table 2. Performance and operations strategy

\begin{tabular}{lc}
\hline & Standardized Coefficients \\
\cline { 2 - 2 } & Performance \\
\hline Operations Strategy & $0.126^{*}$ \\
\hline$* \mathrm{p}<0.00,{ }^{* *} \mathrm{p}<0.05$ &
\end{tabular}

Table 3. Moderating role of job satisfaction and operations strategy in the relationship between entrepreneurial personality and performance

\begin{tabular}{lc}
\hline & Standardized Coefficients \\
\cline { 2 - 2 } & Entrepreneurial Personality \\
\hline Performance & $0.186^{* *}$ \\
Job Satisfaction & 0.014 \\
Operations Strategy & $0.122^{*}$ \\
Entrepreneurial Personality* Job Satisfaction & 0.007 \\
Entrepreneurial Personality * Operations Strategy & $0.051^{* *}$ \\
\hline
\end{tabular}

${ }^{*} \mathrm{p}<0.00,{ }^{* *} \mathrm{p}<0.05$

\section{Conclusion}

The statistically significant relationship between entrepreneurial personality and operations strategy and performance indicate that entrepreneurs have mastered the ability to consistently align all of their operations with customer values while sustaining a smooth productive flow. Entrepreneurs are able to convert operations strategy into results in their respective organizations which is reflected in the performance. This may be easier in small organizations run by entrepreneurs compared to large organization where it may be a difficult task to align everyone in the organization to their operations strategy in particular and strategy in general where they see that their individual work matters to the organization based on the goals defined in the organizational strategic plan. The statistically significant moderating effect of operations strategy in relationship between entrepreneurial personality and performance indicate that having an operations strategy in place allows entrepreneurs to connect with key partners i.e. customers and suppliers which in turn helps them avoid or diffuse competitive escalation in the market place. By partnering with customers and suppliers, entrepreneurs are able to strengthen their strategic position and better understanding of value chain and in turn enhance their organizational performance.

The results of this study could be further examined in the context of corporate entrepreneurship as means for corporations to enhance the strategy development capabilities of their employees and, at the same time increase the corporate success. With the shortening of product life cycles and worldwide uncertain economic conditions, it makes more sense for companies to develop the entrepreneurial personality of their employees so they are ready as an individual to help their organization with market uncertainties.

\section{Limitation \& Future Research}

Although some the results of this research are in agreement with the existing literatures, our research possesses limitations associated with generalization. Our sample of United States based SMEs may limit the generalization 
of our results. Future research should focus on conducting similar study for SMEs based in different countries around the globe. It would be interesting to see if there are differences between SMEs in developing and developed countries. Other limitation might be the lack of control variables and our focus mainly on internal variables affecting performance whereas external factors such as economic conditions could affect the performance as well. Future research should take control variables such as economic conditions into account while analyzing data. Future research would extend the current study and help in generalization of current results.

\section{References}

Acs, Zoltan J. (1999). Are Small Firms Important? Boston: Kluwer Academic Publishers. http://dx.doi.org/10.1007/978-1-4615-5173-7

Ahmed N. U., Montagno R. V., \& Firenze R. J. (1996). Operations Strategy and Organizational Performance: An Empirical Study. International Journal of Operations \& Production Management, 16(5), 41-53. http://dx.doi.org/10.1108/01443579610113933

Armstrong J. Scott., \& Overton, Terry S. (1977). Estimating Non-response Bias in Mail Surveys. Journal of Marketing Research (JMR), 14(3), 396-402. http://dx.doi.org/10.2307/3150783

Baum R. J., \& Locke E. A. (2004). The Relationship of Entrepreneurial Traits, Skill and Motivation to Subsequent Venture Growth. Journal of Applied Psychology, 89(4), 587-598. http://dx.doi.org/10.1037/0021-9010.89.4.587

Beheshti, H. M. (2004). The Impact of IT on SMEs in the United States. Information Management \& Computer Security, 12(4), 318-327. http://dx.doi.org/10.1108/09685220410553532

Breen, J. P. (2004). Enterprise, Entrepreneurship, and Small Business: Where are the Boundaries. International Journal of Entrepreneurship and Small Business, 1(1-2), 21-34. http://dx.doi.org/10.1504/IJESB.2004.005375

Brown S., Squire B., \& Lewis M., (2010). The Impact of Inclusive and Fragmented Operations Strategy Processes on Operational Performance. International Journal of Production Research, 48(15), 4179-4198. http://dx.doi.org/10.1080/00207540902942883

Churchill, N. C., \& Lewis V. L. (1986). Entrepreneurship Research: Directions and Methods. Cambridge, MA: Ballinger.

Ciavarella, M. A. et al. (2004). The Big Five and Venture Survival: Is There a Linkage. Journal of Business Venturing, 19, 465-483. http://dx.doi.org/10.1016/j.jbusvent.2003.03.001

Cohen, J., \& Cohen, P. (1983). Applied Multiple Regression/Correlation Analyses for the Behavioral Sciences (2nd ed.). Erlbaum: Hillsdale, NJ.

Collins, D. F., \& Moore D. G. (1964). The Enterprising Man. East Lansing: Michigan State University Press.

Cooper A., \& Mehta S. (2006). Preparation for Entrepreneurship: Does it Matter? Journal of Private Equity, 9(4), 6-15. http://dx.doi.org/10.3905/jpe.2006.650441

Cromie, S. (2000). Assessing Entrepreneurial Implications: Some Approaches and Empirical Evidence. European Journal of Work and Organizational Psychology, 9(1), 7-30. http://dx.doi.org/10.1080/135943200398030

Crossman A., \& Abou-Zaki B. (2003). Job Satisfaction and Employee Performance of Lebanese Banking Staff. Journal of Managerial Psychology, 18(4), 368-376. http://dx.doi.org/10.1108/02683940310473118

Crow S. M., \& Hartman S. J. (1995). Can’t Get No Satisfaction. Leadership \& Organization Development Journal, 16(4), 34-38. http://dx.doi.org/10.1108/01437739510089085

Currivan Douglas B. (1999). The Causal Order of Job Satisfaction and Organization Commitment in Models of Employee Turnover. Human Resources Management Review, 9(4), 495. http://dx.doi.org/10.1016/S1053-4822(99)00031-5

De Zoysa A., \& Herath S. K. (2007). The Impact of Owner/Managers' Mentality on Financial Performance of SMEs in Japan: An Empirical Investigation. Journal of Management Development, 26(7), 652-666. http://dx.doi.org/10.1108/02621710710761289

Dickers J. S. E., Jansen P. G. W., De Lange A. H., Vinkenburg C. J., \& Kooij D. (2010). Proactivity, Job 
Characteristics, and Engagement: A Longitudinal Study. Career Development International, 15(1), 59-77. http://dx.doi.org/10.1108/13620431011020899

Drucker, Peter F. (1985). Innovation and Entrepreneurship. New York: Harper.

Frese, M., M. van G., \& Obach M. (2000). How to Plan as a Small Scale Business Owner: Psychological Process Characteristics of Action Strategies and Success. Journal of Small Business Management, 38(2), 1-18.

Furnham A., Eracleous A., \& Chamorro-Premuzic T. (2009). Personality, Motivation and Job Satisfaction: Hertzberg Meets the Big Five. Journal of Managerial Psychology, 24(8), 765-779. http://dx.doi.org/10.1108/02683940910996789

Goldberg, L. (1990). An Alternative 'Description of Personality': The Big Five Factor Structure. Journal of Personality and Social Psychology, 59, 1216-1229. http://dx.doi.org/10.1037/0022-3514.59.6.1216

Gu Z., \& Siu R. C. (2009). Drivers of Job Satisfaction as Related to Work Performance in Macao Casino Hotels: An Investigation Based on Employee Survey. International Journal of Contemporary Hospitality Management, 21(5), 561-568. http://dx.doi.org/10.1108/09596110910967809

Hayes Robert H., Wheelwright Steven C., Kaplan, Robert S., \& Clark, Kim B. (1989). Measuring Manufacturing Performance. McKinsey Quarterly, 4, 73-82.

Herron, L. A., \& Robinson, R. B. (1993). A Structural Model of the Effects of Entrepreneurial Characteristics on $\begin{array}{lllll}\text { Venture Performance. Journal of Business Venturing, 8, 294. } & \text {, }\end{array}$ http://dx.doi.org/10.1016/0883-9026(93)90032-Z

Julian, C. C., \& Ahmed, Z. U. (2012). Factors impacting international entrepreneurship in Malaysia. Journal of Small Business \& Enterprise Development, 19(2), 229-245. http://dx.doi.org/10.1108/14626001211223874

Kerr R. M., \& Greenhalgh G. R. (1991). Aspects of Manufacturing Strategy. Production Planning \& Control, 2(3), 194. http://dx.doi.org/10.1080/09537289108919347

Lambin, J. (1997). Strategic Marketing Management. Cambridge, MA: McGraw-Hill.

Lew, P. (2000). Stages of Growth and Entrepreneurial Growth Career Motivation. International Small Business Journal, 18(3), 81 .

Light, I., \& Rosenstein, C. (1995). Race, Ethnicity, and Entrepreneurship in Urban America. New York: Aldine de Gruyter.

Littunen, H. (2000). Entrepreneurship and the Characteristics of the Entrepreneurial Personality. International Journal of Entrepreneurial Behavior and Research, 6(6), 295-309. http://dx.doi.org/10.1108/13552550010362741

Locke Edwin A. (1969). What is Job Satisfaction? Organizational Behavior \& Human Performance, 4(4), 309-336. http://dx.doi.org/10.1016/0030-5073(69)90013-0

Locke Edwin A. (1970). Job Satisfaction and Job Performance. Organizational Behavior \& Human Performance, 5(5), 484-500. http://dx.doi.org/10.1016/0030-5073(70)90036-X

McCarthy, K. D. (2003). American Creed. Chicago: University of Chicago Press.

McClelland, D. C. (1961). The Achieving Society. New York: Van Nostrand.

McClelland, D. C. (1965). N-achievement and Entrepreneurship: A Longitudinal Study. Journal of Personality and Social Psychology, 1, 389-392. http://dx.doi.org/10.1037/h0021956

McKenna, S. D. (1996). The Darker Side of the Entrepreneur. Leadership \& Organization Development Journal, 17(6), 41-45. http://dx.doi.org/10.1108/01437739610130519

Miner, J. B. (1996). The 4 Routes to Entrepreneurial Success. San Francisco: Berrett-Koehler.

Morrison, A. et al. (2003). Small Business Growth: Intention, Ability, and Opportunity. Journal of Small Business Management, 41(4), 417-425. http://dx.doi.org/10.1111/1540-627X.00092

Neely, A., \& Kennerley, M. (2002). A Framework of the Factors Affecting the Evolution of Performance Measurement Systems. International Journal of Operations and Product Management, 22(11), 1222-1245. http://dx.doi.org/10.1108/01443570210450293

Porter, M. E. (1996). What is Strategy? Harvard Business Review, November-December.

Pun, K. F., Sang, C. K., \& Lau, H. C. W. (2004). A Comparative Analysis of Strategy Determinants in 
Manufacturing: Some Findings in Shanghai and Hong Kong. International Journal of Manufacturing Technology \& Management, 6(5). http://dx.doi.org/10.1504/IJMTM.2004.005673

Qureshi J. A., Hayat K., Mehwish A., \& Sarwat N. (2011). Impact of Job Satisfaction and Organizational Commitment on Employee Performance: Evidence from Pakistan. Interdisciplinary Journal of Contemporary Research in Business, 3(4), 642-657.

Rauch, A., \& Frese, M. (2000). Psychological Approaches to Entrepreneurial Success: A General Model and an Overview of Findings. International Review of Industrial and Organizational Psychology, 15, 101-142.

Reynolds, P. D. (2001). Global Entrepreneurship Monitor: Summary Report. London Business School and Babson College.

Reynolds, Paul D. (1997). Who Starts New Firms? - Preliminary Explorations of Firms-in Gestation. Small Business Economics, 9(5), 449-462. http://dx.doi.org/10.1023/A:1007935726528

Rodriguez-Escudero A. I., Carbonell P., \& Munuera-Aleman J. L. (2010). Positive and Negative Effects of Team Stressors on Job Satisfaction and New Product Performance. Journal of Productive Innovation Management, 27(6), 856-868. http://dx.doi.org/10.1111/j.1540-5885.2010.00756.x

Sandberg, W. R. (1986). New Venture Performance: The Role of Strategy and Industry Structure. Lexington, MA: D.C. Health.

Scarpello, V., \& Campbell, J. (1983). Job Satisfaction: Are all the Parts There? Personnel Psychology, 36, 577-600. http://dx.doi.org/10.1111/j.1744-6570.1983.tb02236.x

Schniederjans M., \& Cao Q. (2009). Alignment of Operations Strategy, Information Strategic Orientation, and Performance: An Empirical Study. International Journal of Production Research, 47(10), 2535-2563. http://dx.doi.org/10.1080/00207540701673465

Schumpeter, A. (1934). The Theory of Economic Development. Cambridge, Mass: Harvard University Press.

Sexton, D. L., \& Bowman, N. B. (1986). Characteristics Analysis of Female Entrepreneurs, Managers, Entrepreneurship Students, and Business Students. Babson College.

Simpson, M. (2004). Small Business Success Factors: The Role of Education and Training. Education + Training, 46(8/9), 481-491. http://dx.doi.org/10.1108/00400910410569605

Skinner, W. (1974). The Focused Factory. Harvard Business Review, May-June, 113-121.

Smith, N. R. (1967). The Entrepreneur and His Firm: The Relationship Between Type of Man and Type of Company. East Lansing: Michigan State University Press.

Stewart, W. H. (1999). A Proclivity for Entrepreneurship: A Comparison of Entrepreneurs, Small Business Owners, and Corporate Managers. Journal of Business Venturing, 14(2), 189-214. http://dx.doi.org/10.1016/S0883-9026(97)00070-0

Swamidass, P. M., Darlow, N., \& Baines, T. (2001). Evolving Forms of Manufacturing Strategy Development. International Journal of Operations \& Production Management, 21(9/10), 1289. http://dx.doi.org/10.1108/EUM0000000005971

Swamidass, Paul M., \& Newell, W. T. (1987). Manufacturing Strategy, Environmental Uncertainty and Performance: A Path Analytic Model. Management Science, 33(4). http://dx.doi.org/10.1287/mnsc.33.4.509

Thomas A., Buboltz W. C., \& Winkelspechy C. S. (2004). Job Characteristics and Personality as Predictors of Job Satisfaction. International Journal of Organizational Analysis, 12(2), 205-219. http://dx.doi.org/10.1108/eb028993

Thurik, R., \& Wennekers, S. (2004). Entrepreneurship: Small Business and Economic Growth. Journal of Small Business and Enterprise Development, 11(1), 140-149. http://dx.doi.org/10.1108/14626000410519173

Welsch, H. P., \& Young, E. C. (1982). The Information Source Selection Decision: The Role of Entrepreneurial Characteristics. The Journal of Small Business Management, 20(4), 49-57.

Wheelwright, S. C., \& Hayes, R. H. (1985). Competing through Manufacturing. Harvard Business Review, 63(1), 99-109.

Wickham, P. A. (1998). Strategic Entrepreneurship: A Decision Making Approach to New Venture Creation and Management. London: Pittman.

Wijewardena H., Nanayakkara G., \& De Zoysa A. (2008). The Owner/Manager's Mentality and the Financial 
Performance of SMEs. Journal of Small Business and Enterprise Development, 15(1), 150-161.

Zacharakis, A. (2002). Business Risk, Investment Risk, and Syndication of Venture Capital Deals. Arthur M. Blank Center of Entrepreneurship: Babson College.

Zacharakis, A. (2003). Entrepreneurship Research in Emergence: Past Trends and Future Directions. Journal of Management, 23(3), 285-308. http://dx.doi.org/10.1108/14626000810850892 